\title{
THE NARRATIVE DISCOURSE OF INTERETHNIC BEHAVIOURS AND RELATIONS: THE CONTESTATION OF ETHNIC IDENTITY
}

\author{
Susana Widyastuti \\ Universitas Negeri Yogyakarta \\ email: susana_widyastuti@uny.ac.id
}

\begin{abstract}
Drawing from Discursive Social Psychology (DSP) (Potter, 1998; Potter \& Edwards, 2001), this study is concerned with how attitudes, behaviours, and identity can be observed through language in use or discourse. Focusing on the narratives of the marginalized Chinese Indonesians, the study is particularly aimed at revealing behaviours in coping with the majority group, and how such behaviours may in turn shape intergroup relations and ethnic identity. The data were in the form of narratives of personal experience of Chinese Indonesians collected through interviews which were then scrutinized through in-depth analysis within their socio-political contexts. It has been revealed that in dealing with unequal power relations, two behaviours are embraced convergence and divergence - which are manifested in various discursive and social practices of adapting to the wider society and maintaining aspects of ethnic identity. Any choice of behaviours can have consequences for interethnic relations and ethnic identities. The ideological power exercised by different regimes has obviously constructed ethnic identities and thus made it historically and ideologically contested. The contestation is discursively articulated through the negotiation between ethnic and national identity, the labelling practice using the words Cina and Tionghoa, and the perpetuation of stereotypes associated with the ethnic group.
\end{abstract}

Keywords: ethnicity, discourse, identity, social-psychology

\section{WACANA NARATIF PERILAKU DAN HUBUNGAN ANTAR ETNIS: KONTESTASI IDENTITAS ETNIS}

\begin{abstract}
Abstrak
Dengan merujuk pada Discursive Social Psychology (DSP) (Potter, 1998; Potter \& Edwards, 2001), penelitian ini mengkaji bagaimana sikap, perilaku, serta identitas dapat dianalisis melalui bahasa atau wacana. Dengan berfokus pada narasi etnis minoritas Tionghoa, penelitian bertujuan untuk mengungkap sikap dan perilaku dalam menghadapi kelompok mayoritas dan bagaimana sikap dan perilaku ini berpengaruh pada hubungan antar etnis dan konstruksi identitas. Data berupa narasi pengalaman hidup etnis Tionghoa yang didapatkan melalui wawancara dan dianalisis secara mendalam dalam konteks sosial politik yang melatarbelakanginya. Hasil penelitian menunjukkan bahwa dalam menghadapi isu hubungan antar etnis yang timpang kekuasaan, dua strategi diadopsi,
\end{abstract}


yaitu convergence dan divergence, yang termanifestasi dalam berbagai wacana dan praktek sosial dalam beradaptasi dengan kelompok mayoritas dan juga dalam mempertahankan identitas etnis. Pilihan apapun yang diambil berpengaruh pada hubungan antar etnis dan konstruksi identitas etnis. Kekuasaan ideologi antar rezim telah secara jelas membentuk identitas etnis, sehingga identitas etnis terkontestasi secara historis dan ideologis. Kontestasi tersebut secara diskursus dapat dilihat dalam negosiasi tidak sepadan antara identitas etnis dan nasional, pemberian label dengan menggunakan kata Cina dan Tionghoa, serta dipertahankannya stereotipe terhadap kelompok etnis minoritas tersebut.

Kata kunci: etnisitas, wacana, identitas, sosial psikologi

\section{INTRODUCTION}

This study adopts the principles of Discursive Social Psychology (DSP) (e.g. Potter, 1998; Potter \& Edwards, 2001; Wetherell, 2007), the application of concepts from discourse analysis to central topics in social psychology, in order to reveal the discursive patterns of the emerging social psychological issues, i.e. attitudes, behaviours and identity, from socially-situated narratives. It seeks to reveal how attitudes and behaviours of individuals are manifested in and through narratives within intergroup context. Narratives are believed to be important not just because they reflect what is going on in the history of people's lives but also because they provide insights into the ways in which people, individually and collectively, understand and interpret the world (see Schegloff, 1992, 1997). The close relation between narratives and the world is particularly relevant in this study because it deals with narratives that are simultaneously born out of experience and give shape to experience (see Ochs \& Capps, 1996) within a particular social setting. As a means for recounting past events (Labov, 1972; Labov \& Waletzky, 1967; Ochs \& Capps, 1996), narratives of experience exhibit how people understand and interpret a historical event and, at the same time, reveal the discourse and social practice underlying the narrative construction. The significance of the temporal aspect of narratives can be understood through Bourdieu's concept of 'habitus' (Bourdieu, 1977), which foregrounds that the construction of such narratives involves digging into memory. On this premise Bourdieu argues that people's present identity is embedded in cultural and social currents, constructed through social histories, and internalized by the individual as habitus.

The two notions, 'attitudes' and 'behaviours', have been used hand in hand on the basis that attitudes and behaviours are interconnected and can influence each other (Ajzen \& Fishbein, 1980). 'Attitude' can be conceptualized as a relatively stable organization of beliefs, feelings, and behavioural tendencies towards socially significant objects, groups, events or symbols (Hogg \& Vaughan, 2005). This is to say that the way people judge these things can determine whether people react or behave favourably or unfavourably to them (Eagly \& Chaiken, 1993). For example, 
people are likely to avoid meeting people they dislike, and spend more time and money on things they like.

In an inter-group context, social or collective identity can be constructed through the way people perceive and compare their own group with other groups (Turner \& West, 2010). Tajfel $(1974,1978)$ argues that people show tendencies to evaluate their ethnic ingroup positively and ethnic out-groups negatively, in order to build their own ingroup self-esteem and positive social identity. Such positive or negative categorization and perceptions of ingroups or out-groups may affect attitudes and behaviours in inter-group relations. Put simply, people may choose to maintain distance from the other group or to accommodate them depending on how they perceive the identity of their own group and that of the other group.

Premised on this, there are two possibilities for people's reactions when faced with an identity different from theirs, i.e. convergence and divergence (see Giles, Coupland, \& Coupland, 1991; Giles \& Smith, 1979). Convergence can be conceptualized as a strategy where individuals adapt to another group's identity (e.g. culture and values) in order to reduce or minimize inter-group difference. It signals attitudes such as 'liking' and the 'desire' to be socially closer to the out-group. One particular motive for convergence is the desire to obtain approval or acceptance from the dominant group in particular (Giles et al., 2007). Divergence can be defined as the way individuals seek to preserve their group identity so as to accentuate social and cultural difference between themselves and others.

Taking the context of the intergroup relations between Chinese Indonesians and the majority Indonesians, this study believes that identity and its construction is tied to specific historical contexts and that existing social relations between the Self and the Other are reproduced or contested. Because discourse can only be interpreted and explained in its specific context, the context in which the discursive practice takes place needs to be made explicit and clear. Socio-historical context is crucial as it provides background information for the interpretation and explanation of the findings of the available data. To do so, this study seeks to highlights the key issues embedded in power relations between the minority and the majority in Indonesia and how they are perceived by the Chinese ethnic group. The majority here refers to the mainstream, who call themselves as 'Indonesians' inheriting the Indonesian 'indigenous blood'. It is the 'blood' which was believed to become the basis of othering practices of Chinese Indonesians for generations separating the non-native from the native Indonesians. Although this nativenessbased distinction has been banned by the current government (Aguilar, 2001) and Chinese Indonesians themselves have been an integral part of Indonesia for generations, they have been othered from the whole community of the nation for various socio-political reasons throughout history.

Studies on the minority group's perspectives towards the majority group have been carried out in various context and from different perspectives. 
Guimond, de la Sablonnière, and Nugier (2014) integrate sociological and political perspectives to investigate how intergroup ideologies are institutionalised as policies and highlight that, as such, they often vary across countries and across time. They underline the ideological approaches underlying the question of when and why national policies can shape individuals' intergroup attitudes and beliefs and improve intergroup relations. Focusing on Israeli and Palestinian context, Hammack (2006) undertakes a cultural psychology approach to scrutinize the intergroup identity construction of adolescents from both countries through their life stories and has identified the challenges of identity intervention in the context of intractable conflict. Research in this area has paid scant attention to the discourse analysis of such topic of intergroup relations, which particularly places the issues within relevant social and political context. Considering the interdisciplinary nature of the discourses, this study seeks to cope with multiple perspectives embedded in the principles of Discursive Social Psychology (DSP) in order to provide deeper and fruitful analysis within the wider socio-political context.

\section{METHODS}

The main data of the study were derived from interviews with three Chinese participants from different background, i.e. business, education and church. The interviews were carried out in Indonesian which were then translated for publication purpose. In the interview, the questions were delivered in such a way to elicit participants' personal stories given their identity as individuals of Chinese descent in Indonesia. This was accomplished by using open-ended questions and a semi-structured interview format (Richards \& Talmy, 2011; Riessman, 1993, 2001; Talmy, 2010), allowing the interviewee to construct his or her narrative in the manner she or he was comfortable with. Demographic and background information on the participants was collected through direct questioning the participants before the interview began. Due to the ethical principles that limit the amount of personal information about the lives of the participant, it is not possible to provide a full picture of the participants. Their names were also made pseudonyms.

The analysis privileged the singularity and uniqueness of each narrated story and sought to maintain faithfulness to historical details in biographical narratives (Somers, 1994). A cross-case examination was also adopted, allowing me to see the discursive patterns constructed by recurrences and emergences of discourses in the singular phase so as to provide overarching explanatory illumination of the issues being addressed in the study.

\section{RESULTS AND DISCUSSION Results}

The discourses constructed in each participant's story are unique as they are biographical and are thus shaped by personal background and history. Nevertheless, it is important to note that in some ways the participants share similar accounts for they somehow have common burdens and values as Chinese Indonesians. The interesting thing about 
narratives of personal experience is that there are so many emerging discourses as the participants are just telling their story naturally without being interrupted by interview questions. Thus, the stories under investigation are rich with accounts about their social psychological state as Chinese descents in responding to the wider Indonesian society.

The results show that behaviours, identity construction and interethnic relations are discursively interconnected in the narratives within the context of the study (Diagram 1)

First of all, the narratives demonstrate various discourses and practices which reveal participants' behaviours in coping with the majority group. The practices are manifested from their everyday context in the neighborhood to workplace context in which they have to deal with differences in various aspects of group identity such as values, cultures, and beliefs. The practices can be classified into two types of behaviours, i.e. convergence and divergence. There are some cases, however, when the two behaviours are adopted concurrently. This is to say that at times they seek to adapt to the mainstream while retaining certain aspects of their ethnic identity. In terms of intergroup relations, their openness to people from different ethnic groups from time to time has become meaningful opportunities for Chinese Indonesians to have positive experiences in building stronger social interactions. Despite the socio-cultural challenges they may face, participants seem understand that they need to take necessary actions to be accommodated in the wider society so as to build harmonious inter-group relations.

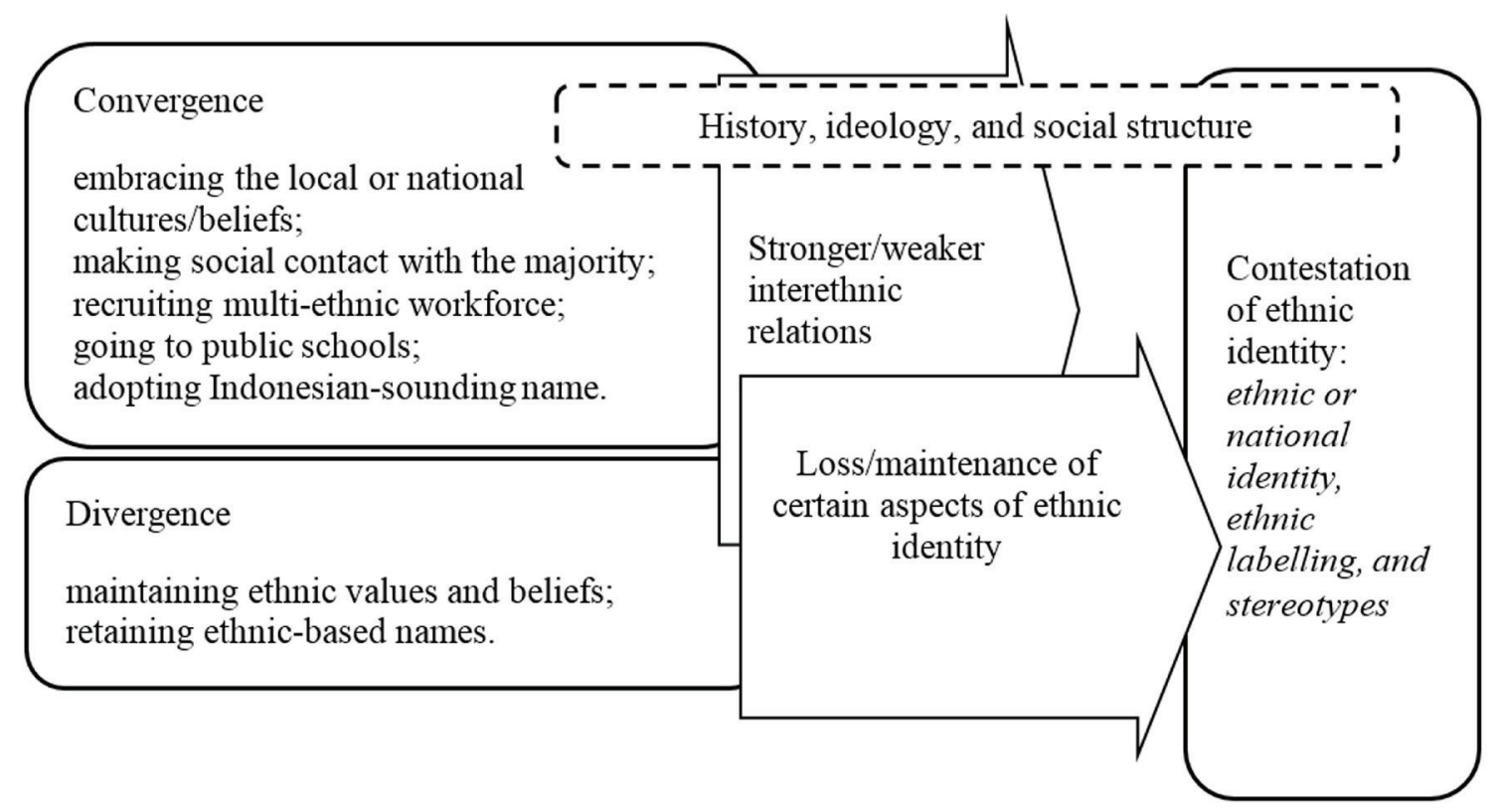

Diagram 1. The correlations between behaviours, identity construction and interethnic relations 
Such convergence or divergence behaviours concern the way Chinese Indonesians deal with problems pertaining to negotiating their place or identity within the wider Indonesian society. The negotiation or contestation is evident in the narratives, denoting that the place or identity of Chinese Indonesians is to be seen from the perspectives of the minority group (how they react to the majority group) and how their efforts may be responded by the majority group. In any case, any behaviours adopted by the group may result in either stronger maintenance or possible loss of aspects of personal or social identity. In the situation when the two behaviours are concurrently adopted, contestation may take place. The contestation is discursively apparent in various discourses in relation to which 'name' they should adopt, which 'label' or 'address terms' should be used to refer to the group, and which 'narrative' should be assigned to the group. In a nutshell, the issues surrounding Chinese or Indonesian-sounding name, Cina or Tionghoa name-calling, and the past or the present identity are still problematic in the discourses of Chinese-ness in Indonesia.

Overall, the narratives highlight that the minority's behaviours, the construction of ethnic identity and the ability of the minority to cope and build relations with the majority are heavily shaped by history, ideology and social structure. It is surprising to find that no matter how hard the minority have tried to assimilate with the majority, there is no guarantee that they can be fully accepted in the wider society. The question to address in this study is thus why are the Chinese descents considered an exceptional ethnic group despite their efforts to assimilate nationally? This can only be understood by looking at how 'the stories' and the underlying ideology about the ethnic group change over time throughout different regimes.

\section{Discussion}

The analysis privileged the nature of the narratives as biographical and historical discourse, thus here the research results (see Diagram 1) are explored in such a way to articulate and allow the naturalness of their stories.

\section{Intergroup Behaviours and Relations}

Various instances of behaviours and relevant discourses emerging from the narratives in relation to how participants deal with the mainstream are shown in extracts 1 - 8. Participants adopted various ways of practising convergence, for instance, Xi Zuan made the interethnic contact in every day interactions and in business practices. Suantara and Petrus merged into Indonesian cultures through their job and education regardless the discrimination they had experienced. The way they perceived the world of the minority - the majority relations and problems in the Indonesian context was positive. Suantara, in particular, decided to leave his Chinese trading tradition or culture and absorbed the culture commonly practiced by people in general.

Extract $1 \mathrm{Xi}$ Zuan, a business man 
1. I don't know why Chinese people were hated... Because in the village

2. where I lived I had good interactions with Javanese people. My hobby was

3. watching puppetry shows. I memorized all the stories in wayang (Javanese

4. puppetry). I knew the culture very well. Then I started asking: why did

5. they call me Cina? My grandfather's friends were all Indonesians,

6. Javanese. My grandfather made friends with Indonesians, Javanese, and

7. then with the Arabs - people of Arab descent, I mean.

At the beginning of the quote (extract 1), a Chinese businessman named $\mathrm{Xi}$ Zuan posed a question he had never been able to answer: why his ethnic group was hated. The question was contradicted by the fact that he and his family had attempted to interact with the Indonesian majority and to adopt their cultures. The notion 'wayang' (puppet show) and how he was fond of the puppet stories was a cultural construct that marks his assimilation into the Indonesian, Javanese in particular, society. Yet this was not enough to make him and his family welcome in the society. That said, no matter how hard the Chinese communities tried to assimilate, they had always been overlooked, made aliens, and called 'Cina' (China/Chinese) due to their Chinese roots $(1.4-5)$.

Further in extract 2 (the continuation of extract 1), remarkably, he managed to overcome his difficulties and, at the time of the interview, Xi Zuan was running a successful advertising company. Here, he asserted that he was able to settle his psychological issues of possible hatred or trauma resulting from the past. Comparing himself with his grandfather, he said "I don't have any problems (with non-Chinese ethnic groups) either" (2.8).

Extract $2 \mathrm{Xi}$ Zuan, a business man

8. I don't have problems either, my staff are all Javanese. Some are

9. Sundanese, some are Tionghoa. I never discriminate against them .... If

10. you want to know, they like working with me.

Extract 3 confirms his positive attitudes in working with people from culturally and ethnically diverse backgrounds. His willingness to create an inclusive environment strengthened his relationships with his own employess and with the local community. His positive perspective encouraged him to create a workplace that reflected the composition of ethnically diverse Indonesians. His stand was also reflected in his cynical view towards people, including his own ethnic group, who tended to be exclusive and thus favored only people from their ethnic group.

Extract 3 Xi Zuan, a business man 
11. I don't like it when Chinese people only recruit Chinese employees. I

12. don't like it. Even, in quotation, I hate them. Why should we be like that?

13. And I also don't like employers, say from other ethnic groups, who also

14. prioritize their own ethnic group or do not have Tionghoa employees.

15. There are some. Many of them are Tionghoa people.

Another participant named Suantara was a Chinese man born in a businessminded family who decided to be a teacher as his life path. He was raised in a family with strong Chinese business values, with a retail business as their core money source (extract 4). During the New Order period, retail business became the most promising way for Chinese Indonesians to survive in Indonesia, where other opportunities seemed unavailable to them (Tan, 2001). In extract 4 his memory went back to how his family tried to keep the Chinese business tradition by planting business mind in him since he was young. However, he insisted on becoming a teacher, a profession which was considered notable by the majority Indonesians. "It's a long story" (4.16), he started.

Extract 4 Suantara, a teacher

16. It's a long story. My parents were all traders. All my brothers and sisters

17. too. Since I was in the $4^{\text {th }}$ grade elementary school I was taught to be a

18. businessman. But then I thought, "How could my life always be like

19. this? ... I have to enjoy my life, it's not just about money". From then

20. on, I was inspired. ... I wanted to work in a different world. I wanted to

21. work in education. It might be a life calling. Because in education I could

22. serve different people every year. When I finished my junior high, my

23. parents asked, "Do you want to open a new shop?" "No, I still want to

24. continue my study." After finishing high school, they asked me again.

25. After finishing university they asked again. When I was at university,

26. my parents sent me a lot of money, but for my parents that was just a

27. small amount. So, in 1975, for my rent, fees and food I just needed IDR

28. 15,000. But every month I got IDR 100,000 from my parents.

It can be discerned that Suantara had to deal with making a decision between achieving his personal dream to be a teacher, one of Indonesians' favorite job, and fulfilling his parents' wish for him to be a retailer, one of Chinese typical jobs which was literally more promising. His family was well-established as they supported him and gave him more than he needed until he went to university (4.25-28). Thus it would have been easy for him to enjoy a good life as he had had more than enough from his family business. However, Suantara was against the values adopted by most Chinese Indonesia, i.e. life is all about money 
(4.19). For him it was about the satisfaction of enjoying life, about being useful to other people, and about making a difference in the world through education.

The last participant, Petrus, was an educated and experienced person in professional jobs who had the calling to be a pastor. He completed his postgraduate degree and gained good experience and rewards from his career as a management trainer at a well-known private bank and as a sales representative at an automotive company. The company was one of the largest automotive distributors and producers in Indonesia founded by Chinese Indonesians. Both the bank and company largely recruited Chinese workforce. He left his jobs in the promising secular marketplace for a fulltime ministry.

He started to have the feeling of being a member of a minority group and to struggle in discriminatory environment since he was a child (extract 5), particularly because he went to public schools. He implied that it was not common for Chinese children to go to at public schools, "[a]s a result, in one class there were only two or three Chinese students, the rest were native Indonesians" (5.30-31). To deal with this situation, he made friends and assimilated with them.

Extract 5 Petrus, a Chinese pastor

29. That's right. Most of my life I went to public elementary school, junior

30. and high schools ... As a result in one class there were only two or three

31. Chinese students, the rest were native Indonesians. That's why my

32. friends are mostly non-Chinese up to now ... That's what I experienced

33. ... It's true, I really mingled with them.

His memories also took him back to his university and work life, when he was trying to obtain his degree and a job (extract 6). His discourse of being a minority continued as he described the scant number of Chinese students in public universities.

Extract 6 Petrus, a Chinese pastor

34. The most memorable incident was when I was at school. I wanted to go 35. to public university. But it was widely known that the Tionghoa, who 36. happened to be Christian, were not given much opportunity. Only a very 37. small number of them were allowed in a faculty or a study program. That 38. was in the early 1990s, 1991 yeah. About jobs, I happened not to apply 39. for civil servant jobs. The companies I worked for were all private. So I 40. did not have any problems. We were accepted based on our competence.

41. To the best of my knowledge, about becoming a civil servant, although 42. I never checked the written regulation, it seemed that Chinese 43. Indonesians were not given priority 
The period that Petrus described in extract 6 was the 1990s, the time of social and economic instability in Indonesia in nearly the end of the New Order regime. Petrus described the othering of Chinese Indonesians in the Education and employment. In those education and employment sites (especially public schools and government offices), he personally dealt with the situation due to his 'double minority' identity, as a Chinese and Christian person (6.35-36). In a country in which almost 90 percent of the population is Muslim, Christians are another minority group. As part of his response to discrimination in public sectors and his fear of rejection, he chose to go to a private university and to apply for jobs at private companies.

Another convergence behaviour was the adoption of Indonesian-sounding name. In the interview, both Suantara and Petrus asserted the centrality of being able to assimilate with the host society. This is to say that they were gradually adjusting themselves to the customs and tradition of the mainstream. Name indicates ethnic identity, yet for them name changing does not seem to be an issue as along as they can live together with the others harmoniously.

Xi Zuan had a different perspective about this name changing. While trying to maintain his social contact with the majority, Xi Zuan was faced with the challenge to hold onto aspects of his Chinese identity (extract 7). He showed me his name card with his three Chinese traditional names written on it, a strong indication of his firm attitude to fight for and stand by his ethnic identity and to reject the suggested national identity. One of the reasons for this divergence behaviour, i.e. not adopting a new Indonesian-sounding name, was because it would cost much (7.47). However, more importantly, for him, changing name was not important because "changing names does not reflect people's sense of nationalism ... right?" (7.45-46). For him, his strong commitment to ethnic identity does not necessarily mean that he does not love Indonesia and that he withdraws himself from the wider community. The context of his account about name-changing was the assimmilation policy enacted by the New Order administration. When Suharto came to power, anti-Chinese regulations were enacted to erase or restrict any practice or form of Chinese culture in the state, such as Decree of Presidium Cabinet 127/U/12/1966 which forced the ethnic Chinese to adopt an Indonesian-sounding name instead of the standard Chinese name (Heryanto, 1998).

Extract 7 Xi Zuan, a business man

44 This is my business card. Here you can see I have three [Chinese] names, 45 I did not change my name. Because changing names does not reflect 46 people's sense of nationalism... right? At that time everyone was forced 47 to change theirname. Eventually I decided to reject it, anyway I did not have the money 
Given the participants' positive attitudes towards the social reality of intergroup relations, the question posed next was "Did embracing the Indonesian culture make them accommodated in the society?" As a consequence of his being accommodative to non-Chinese people, $\mathrm{Xi}$ Zuan said elsewhere in the interview that the local people protected his family and workplace from the mobs during the May Riots in 1998. His positive outlook towards life and people can also be seen from the non-Chinese (mixed-ethnic) employees he recruited without discri- minating against them (see extract 2).

At the time of the interview, Suantara had become an experienced educator and a curriculum coordinator. However, it should be noted that his decision to leave his family business and to press ahead with his teaching passion was not easy, especially at the early stage of his career. At his first school, he had to face stereotyping assumptions about his teaching because people tried to connect his teaching materials to his ethnic background (8.49).

Extract 8 Suantara, a Chinese teacher

48. It (his first school) was so different. I first taught there, and they said like

49. "Oh no, this is Chinese math"

Overall, the narratives suggest three points in relation to the behaviours. First, convergence and divergence are not necessarily mutually exclusive (see Giles \& Ogay, 2007). When individuals seek to build social contact, aspects of divergence and/or convergence can concurrently take place depending on the situation and the need for accommodation (see Xi Zuan's accounts, particularly extract 7). This is to say that there is no pure convergence or divergence and the two are intertwined in the social psychological process of ethnic accommodation. In other words, convergence and divergence are not only about a person's response to the other group's identity, they also explain how people engage with their own identity while seeking to disaccommodate or accommodate the other group's identity. There are possibilities when a person embraces these two behaviours, which is called integration or mutual accommodation (Berry, 1997), a strategy which requires acceptance by both groups and acknowledges different aspects of identity.

Second, the socio-psychological state of individuals towards the society, which particularly poses them with sociocultural challenges, shapes their intergroup behaviours. If we look at the participants' biography, the way they look at their life has affected their view, attitudes and behaviours to people around them. That said, their life trajectory, what happened to them in their life and how they became what they are now, has largely shaped their ability to deal and engage with the Indonesian majority. Suantara's progressive values about life which seem not in line with what his family and most Chinese Indonesians traditionally believe have shaped his personal response in dealing with the environment where he is considered as 
an alien. The same is true with Xi Zuan, his openness to members and cultures of other ethnic groups can be the results a long experience of being othered. On the other hand, his firm response to the Indonesian-sonding name policy somehow can be a strategy to reduce the effects of the rejection so as to build selfesteem.

Third, their attitudes towards the Indonesian majority and how far they are able to adapt to the majority cultures or maintain aspects of their ethnic identity are largely shaped by socio-political context or the regime's ideology. The discourses about equality in education and employment articulated in extract 6 are strong evidences of how the broader (discriminatory) environment may affect people's ability to assimilate with the majority group. In a more institutional context, the regulations mandated by the New Order, e.g. the adoption of Indonesian-sounding name, encourage Chinese Indonesians to absorb the national cultures and identity. While this is not an easy decision to make, adopting the name does not necessarily imply social and political equality (see extract 6). This issue is all about the ideological aspect of ethnic identity which I will discuss in the next section.

\section{The Contestation of Identity: Unequal} Power Relations, Labelling, and Stereotypes

What stands out from the narratives is that the participants seek to positively embrace the social and political realities, i.e. unequal power relations between the Chinese minority and Indonesian majority, and that they seem to understand that adopting the Indonesian values and establishing good relations with the majority are the only ways they can be accepted in the society. What can be highlighted here is that any choice of behaviours can have consequences for one's identity, i.e. it may lead to either stronger maintenance or possible loss of aspects of personal or social identity (Giles et al., 1991). The narratives also suggest that identity construction is complex, historical, an ideological. It undergoes changes and contestation overtime throughout different regimes.

First, identity is ideologically contested for there are strong correlations between ethnic identity, acceptance of cultural difference and adaptation to the national identity (Phinney, Horenczyk, Liebkind, \& Vedder, 2001). People may have a concurrent commitment to both the heritage identity and the dominant culture practised in the wider society. Accordingly, in socio-cultural interaction, boundaries between in-group and outgroup identity or between ethnic and national identity are contested. Xi Zuan keeps practicing the balance between convergence and divergence. He is able to build a close interaction with the Indonesian communities in his neighbourhood (extract 1) and with the workers in his advertising company who come from different ethnic groups (extract 2). Given the hostility and identity threat he has faced, it could be difficult for him to maintain his ethnic identity. He, however, is able to maintain aspects of his cultural and ethnic identity while emphasizing solidarity in dealing with the majority. By sticking to his Chinese name (extract 7) while adopting the local culture, Xi Zuan has accentuated 
the difference between himself and the Indonesian majority in a positive manner. In other words, he managed to 'live with' difference, rather than to 'overcome' and 'get rid' of difference.

The contestation between ethnic and national identities reflects two realities throughout the socio-political life of Chinese Indonesians in Indonesia: that they are required and expected to blend with the mainstream (as part of the effect of the assimilation program mandated by the New Order regime in 1966) if they wish to be acknowledged in the wider society and that they naturally have a close connection to their ethnic values. Heryanto (1998) in particular highlights the issue of identity loss, using his term 'identity erasure', to point out the assimilation program which suggests Chinese Indonesians to adopt Indonesiansounding name. 'Name' thus becomes a central identifier of one's ethnicity, explains how far they have merged into the local culture or society, and reveals how national ideology and social order may influence one's ethnic identity. The discourses underlying the name changing issue are thus complex and one's decision whether or not to adhere to the regulation may be motivated by various reasons such as political, economic and social motives.

Secondly, the contestation is clearly visible in the discourses embedded in three terms used by the participants to label themselves, i.e. Cina, Tionghoa, and Chinese. These words are not translated in the extracts. They are used differently to refer to different situation. Cina emerges in a negative discourse when $\mathrm{Xi}$ Zuan questions his identity assignment through the name calling, "Why did they call me Cina?" (1.4). This term is used by the majority Indonesians (they) to refer to Chinese Indonesians. Questioning the Cina labelling means not wanting, disliking or refusing it. Tionghoa appears several times and is used by the Chinese participants to refer to themselves as Chinese descent, e.g. "Some are Sundanese, some are Tionghoa" (2. 8-9), "Many of them are Tionghoa people" (3.14-15), and "But it was widely known that the Tionghoa, who happened to be Christian, were not given much opportunity" (6.35-36). Tionghoa has positive connotation. Chinese is more neutral and general in a way that it is a loan word from English to refer to the group, e.g. "I don't know why Chinese people were hated" (1.1), and "I don't like it when Chinese people only recruit Chinese employees" (3.11). Thus, the use of Cina and Tionghoa bring in important insights into identity construction, i.e. the way the majority perceive them (Cina) and the way the Chinese group look at themselves (Tionghoa).

The discourses of Cina versus Tionghoa are historical and have emerged since the era of Susilo Bambang Yudhoyono (2004 - 2014) who addressed issues of Chinese identity, mandating the use of Tionghoa instead of Cina to refer to the ethnic members and Tiongkok (from the Hokkian word 'Tiong-Kok' or middle kingdom) to refer to the Republic of China. In doing so, Yudhoyono annulled the Cabinet Presidium issued Circular no. SE-06 (1967), which asked all Indonesian publications to use Tjina (the old spelling of Cina) to replace Tiongkok or Tionghoa. Since the term Cina was 
introduced by the forces of Western civilization which once tore China apart, it bore a continuing sense of insult to Chinese Indonesians because it implied they were 'inlander' or 'uncivilized'. The shift from Cina to Tionghoa has thus ideologically marked acceptance of the ethnic Chinese as an integral ethnic group in Indonesia (Suryadinata, 2008). XiZuan's question (extras 1) demonstrates that, in every day practice, the vast majority of Indonesians still associate them to their blood or origins regardless the regulation. Thus, in intergroup context, ideologies are not located solely within individual minds, yet they are sometimes widely shared by members of a social group (Guimond et al., 2014).

Third, despite the positive attitudes of Chinese Indonesians, stereotypes attached to the group are still prevalent. Stereotypes deserve a special attention here as they have succeeded in perpetuating intergroup conflicts in the past and can affect inter-group relations (Tan, 2001). Stereotypes are one key piece of evidence for the presence of the past in the present situation which constitutes various challenges for Chinese Indonesians. This shows that identity is contested throughout history. The response received by Suantara when teaching math, i.e. "Oh no, this is Chinese math" (8.49) can be a good instance for this. This ongoing stereotype assigns the ethnic group with their delicate and careful calculating system. When relating it to his teaching performance, this stereotype may be seen in either as positive or negative sense. This 'Chinese math' has been understood as one of the practices underlying why Chinese
Indonesians are generally perceived as resilient, hard-working people, and economically-established (Chua, 2008).

The positive intergroup behaviours also break the stereotype that Chinese Indonesians are socially exclusive. Such negative perception about the ethnic Chinese that is widely shared is often misleading and thus becomes one of the many reasons why the ethnic Chinese are still considered "the other". Yet, it is obvious that the participants are aware that they need to be involved actively or to initiate necessary actions to be accommodated in the wider society. Giblin (2003) in particular addresses the attempts taken by a number of organizations by Chinese Indonesians to overcome this particular stereotype which has proliferated in Indonesia. This should be seen a good sign for the creation of a more accommodative and multicultural environment where Chinese Indonesians can get involved in more social activities.

\section{CONCLUSIONS}

Focusing on participants' behaviours and relevant discourses embedded in the narratives, this discourse study has demonstrated the social psychological state of individuals when seeking to make meaning of, cope with, and overcome social problems, given their identity as a minority group and the unequal power relations between the ethnic minority and the national majority. After revealing how they deal with the majority group, the study ultimately explores how such behaviours relates to the fostering of positive interethnic relations and illuminates how such 
behaviours construct one's identity within the given socio-historical context. It has also highlighted how ethnic identity is historically and ideologically contested within national context through time. In line with this, ideological power exercised in different regimes has obviously constructed social structure and ethnic identity, shaped relations between the two groups and in turn determined the ability of the minority group to engage with the majority group.

Further research should pay attention at the perspectives of the majority group, focusing on how their attitudes and behaviours towards the minority may also affect the construction of identity and interethnic relations. It has been argued in this study that the environment and the attitudes of the Indonesian majority contribute to the ability of Chinese Indonesians to engage and build social contact with that majority.

\section{ACKNOWLEDGEMENTS}

I would like to extend my appreciation to DIKTI (the Indonesian Directorate General of Higher Education) for its generosity in granting me the research fund for this publication.

\section{REFERENCES}

Aguilar, F. V. (2001). Citizenship, Inheritance, and the Indigenizing of "Orang Chinese" in Indonesia. Positions: East Asia Cultures Critique, 9(3), 501-533. https://muse.jhu. edu/article/27988

Ajzen, I., \& Fishbein, M. (1980). Understanding Attitudes And Predicting Social Behaviour. Englewood Cliffs: Prentice-Hall.
Berry, J. W. (1997). Immigration, Acculturation, and Adaptation. Applied Psychology: An International Review, 46 (1), 5-34. doi:10.1111/ j.1464-0597.1997.tb01087.x

Bourdieu, P. (1977). Outline of a Theory of Practice. Cambridge: Cambridge University Press.

Chua, C. (2008). Chinese Big Business in Indonesia: The State of Capital. London: Routledge.

Eagly, A. H., \& Chaiken, S. (1993). The Psychology of Attitudes: Harcourt Brace Jovanovich College Publishers. Giblin, S. (2003). Civil Society Groups Overcoming Stereotypes? Chinese Indonesian Civil Society Groups in Post-Suharto Indonesia. Asian Ethnicity, 4(3), 353 . doi: 10.1080/1343900032000117196

Giles, H., Coupland, J., \& Coupland, N. (1991). Accommodation Theory: Communication, Context, and Consequence. In H. Giles, J. Coupland, \& N. Coupland (Eds.), Contexts of Accommodation. New York: Cambridge University Press.

Giles, H., Hajek, C., Barker, V., Lin, M.-C., Zhang, Y. B., Hummerst, M. L., \& Anderson, M. C. (2007). Accommodation and Institutional Talk: Communicative Dimensions of Police-Civilian Interactions. In A. Weatherall, B. M. Watson, \& C. Gallois (Eds.), Language, Discourse and Social Psychology. Basington: Palgrave.

Giles, H., \& Ogay, T. (2007). Communication Accommodation Theory. In B. B. Whaley \& W. Samter (Eds.), Explaining Communication: Contemporary Theories and Exemplars. Mahwah, NJ: awrence Erlbaum. 
Giles, H., \& Smith, P. (1979). Accommodation Theory: Optimal Levels of Convergence. in $\mathrm{H}$. Giles \& R. N. St. Clair (Eds.), Language and Social Psychology. Baltimore: Basil Blackwell.

Guimond, S., de la Sablonnière, R., \& Nugier, A. (2014). Living in a Multicultural World: Intergroup Ideologies and The Societal Context of Intergroup Relations. European Review of Social Psychology, 25(1), 142-188. doi: $10.1080 / 10463283.2014 .957578$

Hammack, P. L. (2006). Identity, Conflict, and Coexistence: Life Stories of Israeli and Palestinian Adolescents. Journal of Adolescent Research, 21(4), 323-369.

Heryanto, A. (1998). Ethnic Identities and erasure: Chinese Indonesians in Public Culture. In J. S. Kahn (Ed.), Southeast Asian Identities (pp. 95-114). Singapore: Institute of Southeast Asian Studies.

Hogg, M. A., \& Vaughan, G. M. (2005). Social psychology. Harlow: Person.

Labov, W. (1972). Language in the Inner City. Philadelphia: University of Pennsylvania Press.

Labov, W., \& Waletzky, J. (1967). Narrative analysis: Oral Versions of Personal Experience. In J. Helm (Ed.), Essays on the Verbal and Visual Arts (pp. 12-44). Seattle/London: University of Washington Press.

Ochs, E., \& Capps, L. (1996). Narrating the Self. Annual Review of Anthropology, 25(1), 19-43. doi: 10.1146/annurev.anthro.25.1.19

Phinney, J. S., Horenczyk, G., Liebkind, K., \& Vedder, P. (2001). Ethnic
Identity, Immigration, and Wellbeing: An Interactional Perspective. Journal of Social Issues, 57(3), 493510. doi:10.1111/0022-4537.00225

Potter, J. (1998). Discursive Social Psychology: From attitudes to Evaluative Practices. European Review of Social Psychology, 9(1), 233-266. doi:10.1080/14792779843000090

Potter, J., \& Edwards, D. (2001). Discursive Social Psychology. The New Handbook of Language and Social Psychology, 9, 103-118.

Richards, K., \& Talmy, S. (2011). Theorizing Qualitative Research Interviews in Applied Linguistics. Applied Linguistics, 32, 1-5 doi: 10.1093/applin/amq045

Riessman, C. K. (1993). Narrative Analysis. Newbury Park, CA: Sage Publications.

Riessman, C. K. (2001). Analysis of Personal Narratives. In J. F. Gubrium \& J. A. Holstein (Eds.), Handbook of Interviewing. London: Sage.

Schegloff, E. A. (1992). In Another Context. In A. Duranti \& C. Goodwin (Eds.), Rethinking Context: Language As an Interactive Phenomenon (pp. 191). Cambridge: Cambridge University Press.

Schegloff, E. A. (1997). Whose text? Whose context? Discourse \& Society, 8(2), 165-187.

Somers, M. R. (1994). The Narrative Constitution of Identity: A Relational and Network Approach. Theory and Society, 23(5), 605-649. doi: $10.2307 / 658090$

Suryadinata, L. (2008). Chinese Indonesians in an Era of globalization: Some Major Characteristics. In L. 
Suryadinata (Ed.), Ethnic Chinese in Contemporary Indonesia. Singapore: ISEAS Publications.

Tajfel, H. (1974). Social Identity and Intergroup Behaviour. Social Science Information, 13(2), 65-93. doi:10.1177/ 053901847401300204

Tajfel, H. (Ed.) (1978). Differentiation Between Social Groups: Studies in the Social psychology of intergroup relations. London: Academic Press.

Talmy, S. (2010). Qualitative interviews in applied linguistics: From Research Instrument to Social Practice. Annual Review of Applied Linguistics, 30, 128$148 . \mathrm{d}$ o i : 10 . 1017 / S0267190510000085
Tan, E. K. B. (2001). From Sojourners to Citizens: Managing the Ethnic Chinese Minority in Indonesia and Malaysia. Ethnic and Racial Studies, 24(6), 949-978. doi:10.1080/01419870120077922

Turner, L. H., \& West, R. (2010). Communication Accommodation Theory. Introducing Communication Theory: Analysis and Application (4th ed.). New York, NY: McGraw-Hill.

Wetherell, M. (2007). A Step Too Far: Discursive Psychology, Linguistic Ethnography and Questions of Identity. Journal of Sociolinguistics, 11 ( 5 ) , $661-681$. d o i : 10.1111/j.1467-9841.2007.00345.x 